\title{
A STUDY OF PRACTICAL EXAMINATIONS: PROVISION AND PRACTICES
}

\author{
Tek Mani Karki \\ Lecturer, Department of English Education, Mahendra Ratna Campus, Kathmandu, TU. \\ Corresponding author:tmkarki@gmail.com
}

\begin{abstract}
Tribhuvan University, Faculty of Education has introduced four-year annual B. Ed. program in 2015. The Department of English Education has offered a course with theory plus practice in nature each year in this program. One of the courses with this nature is 'Research Methodology in English Education', introduced in the fourth year. Concerning the practical portion of this course, this paper highlights the variations of research reports and explores the challenges faced by the subject teachers (internal examiners) and the students selecting five affiliated campuses applying convenient sampling procedure in Bagmati province. Five research reports (one from each campus) selected randomly were analyzed, five teachers and five students (one from each campus) purposively selected were interviewed to gather information, and the data were interpreted thematically. Considerable amount of variation appeared in the research reports in terms of format, content,and citations and referencing style. Challenges occurred when the teachers did not receive clear guidelines from the concerned authorities to uniform the practical works. Students' irregularities seemed another challenge for quality improvement in research works. The challenges can be minimized by implementing the course guidelines in practice. For this, the concerned authorities can organize several programs to support the teachers and to attract the students attending the classes regularly at the campuses.
\end{abstract}

Keywords: research methodology - English education - B. Ed. fourth-year affiliated campus - practical examination - challenge

\section{INTRODUCTION}

Faculty of Education(FoE), the largest faculty in terms of the number of students and the number of campuses (26 constituent and 590 affiliated) under Tribhuvan University (TU), produces trained educational "human resource" as teachers, teacher trainers, educational planners and managers, 
educational researchers, curriculum designers (Tribhuvan University, 2020)and all kinds of human resources needed for the educational sector of the country through its various courses taught in different programs, viz. one-year B. Ed, four-year B. Ed, M. Ed, MPhil, and Ph. D. FoE has been changing its programs, curricula, and duration of the time to study in different programs from time to time since its establishment. Initially, it offered a two-year B. Ed. program before 1996, a three-year program implemented after 1996, and it has been implementing the four-year program since 2015 .

To earn four-year B.Ed. degree, according tothe Faculty of Education (2015), every student must pass twenty-two courses offered in the program. These courses are divided into four major groups excluding the 'teaching practice' course. They study two courses related to 'communication skills' in group ' $\mathrm{A}$ ' in the first year; four courses (one in each year) related to 'professional core areas' in group 'B'; ten courses (two in each first and fourth year, and three in each second and third year) related to 'specialization major areas' in group ' $\mathrm{C}$ '; five courses (one in each first, third and fourth year, and two in the second year) related to the specialization minor areas' in group ' $\mathrm{D}$ '. In addition to these courses, they have another practicum course, i.e. 'teaching practice' in the fourth year.

My major concern in this paper is to study the 'Research Methodology in English Education' offered in the fourth year for the students majoring English. This course has been introduced for the first time at this level. The course is based on theory (50\%) and practice (50\%). It aims to help students understand the basic concepts and processes of doing and writing research in English language education. To achieve this main objective, FOE has designed the course separating it into six different units which are introduced briefly with their focusing on and what the students involved in the 'project work' (I have used the term 'research report' henceforward) in each unit below.

The first unit - the introduction of research — of the course focuses on helping students conceptualize the definition, characteristics, paradigms, and types of research. Similarly, the second unit—basic components of research - deals with the basic components of research, e.g. the process of identifying research problems, framing research questions and objectives, writing a literature review, specifying research methods and data analysis procedure, and writing reports. In the same way, the third unit - methods 
of data collections - focuses on the different methods of data collection while the fourth - research designs - and the fifth-data analysis and interpretation - units deal with different types of research designs, and the way we analyze, interpret and triangulate the qualitative and quantitative data respectively. The final unit-writing research-concentrates on engaging students in writing research reports.

For the practical portion, all the students choose a topic of their interest individually and involve in their work after completing the theoretical part in each unit. Particularly, they should engage in identifying research problems, preparing research questions, setting objectives, and writing a literature review related to the topic they have decided on. They should also work together to specify the methods and data analysis procedures for their study and engage in designing research and collecting data by using appropriate methods and tools. They analyze and interpret the actual data they have collected from the field by using relevant statistical tools and/or constructing themes. Finally, they prepare a complete research report by following appropriate citation and referencing style, i.e. American Psychological Association (2010).

Faculty of Education (2015)has stated that the teacher should help to design the research report of the students in the respective campuses. The curriculum noticeably instructs that the report is required to have 2000-3000 words in its length. The teachers concerning the campuses are strongly suggested that they should provide feedback to the students on their work regarding the format, citation and referencing style of the whole report before evaluating by an external examiner appointed by the Office of the Controller of Examinations (OCE).

In 2019, I visited some campuses of Bagmati province taking an appointment from the OCE as an external examiner to examine the practical examinations of the students as the first batch $(2076 \mathrm{BS})$ of the "Research Methodology in English Education" (Eng. Ed. 445). During this period, I found variations in the research reports they submitted to the campuses. On some campuses, students were ready to take the practical examinations with a few pages irrelevantly copied from their books which they called their research report which was against the provision of the practical examination mentioned in the curriculum provided by the FOE, Tribhuvan University. 
Having observed these situations, I realized that there existed some problems which made me, as a teacher/examiner, curious to know something about the practical activities focusing on the practices with the provision (guidelines provided to the curriculum) observing the reports the students prepared for the examinations and taking the views of the teachers and the students of the selected campuses. Furthermore, the course has become the first experiences of the teachers and the students, and no research studies have been conducted focusing on this topic yet. So, I planned to study this issue preparing the following objectives.

\section{OBJECTIVES}

The objectives of this paper were to (a) describe the variations of the report in practice in relation to the provision in terms of format, content, and citations and referencing style; (b) explore the challenges faced by the teachers (internal examiner) to prepare their students for the practical examinations, and (c) find out the challenges faced by the students (examinees) in preparing the practical portion of this course.

\section{The necessity of practical work: Theoretical perspective}

Practical work/examination is essential for students for many reasons. For Lynch and Ndyetabura (1983), practical work is necessary because it helps the students to (a) make their observations more careful and logically interpret them; (b) make the theoretical parts clearer, more real, and interesting; (c) enable students to find out facts and principles themselves; (d) develop the skills and techniques of practical research work; (e) grow a personal interest in practical work; and (f) encourage for the study of related subjects further in higher level. Another important role of practical work is to help students develop links between observations and ideas (Abrahams \& Millar, 2008).

Faculty of Education (2015) has incorporated a portion of practical work in "Research Methodology in English Education (Eng Ed 445)" with a provision to acquaint the students of B. Ed. fourth year with a general understanding of the nature and characteristics of research methodology in language education; familiarize them with the research problems, questions; enable them to design several types of research relevant to language education; engage them in doing basic research in language education; develop their competencies in analyzing and interpreting data; enhance their skills in writing research reports which are more or less similar to the 
significance of the practical works as pointed out by Lynch and Ndyetabura (1983), and Abrahams and Millar (2008) as mentioned above.

\section{METHODS AND MATERIALS}

In this research, I adopted the "qualitative research design" (Denzin \& Lincoln, 2018; Kumar, 2019; Maxwell, 2013; Tracy, 2020) in which "Qualitative researchers stress on the socially constructed nature of reality, the intimate relationship between the researcher and what is studied, and the situational constraints that shape inquiry... the value-laden nature of inquiry" (Denzin \& Lincoln, 2011, p. 8). In the present research, I assumed the same ontological, epistemological, methodological, and axiological position as explained by Denzin and Lincoln above while describing the variations of research reports prepared by the students and exploring the challenges faced by the teachers and the students in the selected campuses.

I made a plan to study in the affiliated campuses as they cover more than $95 \%$ percent of the total campuses running education programs. To collect the information, I selected five affiliated campuses (three from urban and two from rural areas) of Bagmati province applying a convenient sampling procedure. Interviews with five subject teachers (internal supervisors) and five students (purposively selected from sampled campuses), and document (research reports prepared by students) analysis are the methods of data collection, and interview guidelines and documents are the major tools for the collection of information. To maintain anonymity, I used the pseudonyms as Camp 1...Camp 5 to indicate the sampled campuses and Engt 1...Engt 5 to the teachers and Stud 1...Stud 5 to the students. I interpreted the data by using 'thematic networks' (AttrideStirling, 2001)a tool for analyzing the qualitative information.

To establish the credibility and trustworthiness, I applied some strategies like 'triangulation' (Denzin, 1978)to verify the information; 'member checking' (Lincoln \& Guba, 1985)to check whether participants' ideas are reflected in the interpretation; 'thick/rich description' (Denzin, 1989) to make the research process rigorous and 'collaboration'(Creswell $\&$ Miller, 2000)to work with the participants in each step of the research.

\section{RESULTS AND DISCUSSIONS}

Analyzing five reports, and interviewing five teachers and five students from five campuses, I have generated the themes which are as follows. 


\section{Variations in the research report}

The reports prepared by the students for the practical examinations seem to be varied on the campuses. I have analyzed the reports in three subthemes - format, content, and citations and referencing style.

Format: The format of the reports appeared varied in the sampled campuses. Itincludes the format of the cover page and the structures of the research reports (RP). Figure 1 shows that there is no uniformity in designing the cover pages. RP 1 is a handwritten document and has no specific level and the year it belongs to and it does not mention the title of the research, either. RP 2 has a kind of format but it needs proofreading. Similarly, RP 3 makes confusion about which course and year it is related to. RP 4 mentions "research proposal" at the top and "thesis" just below the title of the research which creates ambiguity to the readers whether it is a proposal or report. RP 5 has a structure but it needs editing.

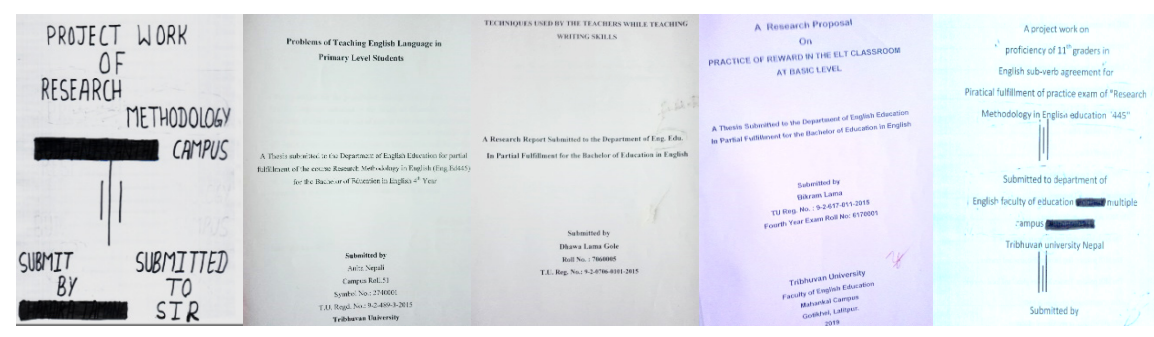

Figure 1: Cover pages of the sampled research reports (from left RP $1 \ldots$ RP 5)

Regarding the structure of the report, all of them are more or less similar, i.e. they have four to five units/chapters. All the reports incorporate the components, such as the background of the study, review of related literature, methodology, analysis and interpretation, and conclusion and recommendations which are commonly incorporated in the research report. Only three of them, RP 2, RP 3, and RP 4 have the preliminary section (information about the report which is written before start writing unit/ chapter I).

Content: Disparities also seem in terms of the content of the reports. The content of RP 1 does not seem to be matched with the content of the common research report. It provides the introduction of the research in chapter I. Similarly, it has explained what is done in each chapter in detail following the general format. It has six pages in total in handwritten text. RP $2(40+8$ pages), RP 3 ( $75+11$ pages), RP 4 ( $40+10$ pages) and RP 5 (14 pages) 
seem to be research-based as the quantitative information is analyzed with table(s) and/or figure(s). Questionnaires they used to collect the data have only been appended in RP 2 and RP 5.

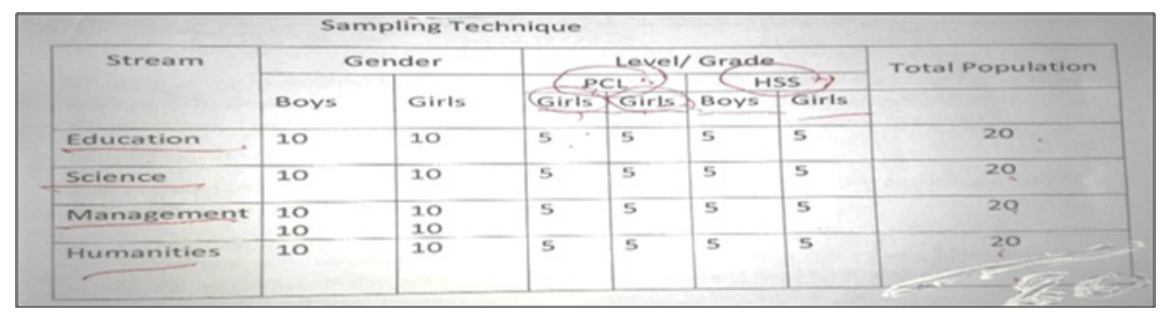

Figure 2: Number of participants for collecting the information used in RP 5 (p. 5)

Unexpectedly, this study found clear evidence of how some of the students cheated on the examiners by preparing the report using the same data already used or creating the imaginative (fake) data for the practical examinations. Figure 2 is an example of it.

3. The students of grade Twelve (HSS ) were found more proficient than the students of PCL second years in English subject-verb agreement because the former students obtained higher mean score (29.97) than the latter students. The means score obtained by the students of PCL second year was only 29.75 .

Figure 3: Finding 3, information obtained from the participants mentioned in Figure 2 (RP 5, p. 5)

According to Figure 2, forty (50\%) participants were chosen from the students studying in PCL (Proficiency Certificate Level) selecting from four streams (faculties) in $2076 \mathrm{BS}$, and Figure 3 presents the finding of the research. This report does not seem to be based on the real data because the PCL program mentioned in the faculties in Figure 2 no longer exists in the present condition. It was phased out about ten years ago. It makes me surprising how this report became eligible for the final evaluation in the practical examinations.

Citations and referencing: In-text citations help to make the authors' statement impressive in academic writing. All and only the cited materials inside the texts are listed in the reference section at the end of the text following the appropriate style. Faculty of Education (2015)expects the APA style in academic writing from all the scholars studying under the 
faculty. The picture of the in-text citations and references used in the sampled research reports are displayed in Table 1 below.

Table 1:Number of the citations listed materials in referencing

\begin{tabular}{lllll}
\hline S.N. & $\begin{array}{l}\text { Research } \\
\text { reports }\end{array}$ & $\begin{array}{l}\text { Total in-text } \\
\text { citations }\end{array}$ & $\begin{array}{l}\text { Total listed } \\
\text { materials in } \\
\text { the reference }\end{array}$ & $\begin{array}{l}\text { Total in-text cited } \\
\text { materials listed in the } \\
\text { reference }\end{array}$ \\
\hline 1. & RP 1 & 0 & 0 & 0 \\
2. & RP 2 & 8 & 7 & 3 \\
3. & RP 3 & 68 & 35 & 19 \\
4. & RP 4 & 40 & 19 & 9 \\
5. & RP 5 & 8 & 5 & 1 \\
\hline
\end{tabular}

Table 1 depicts that the researcher (regarding RP 1) totally ignored the citation and referencing aspects while preparing it. Similarly, a large number of in-text cited materials - 63 percent, 72 percent, 78 percent, and 88 percent - are left uncited in the referencing in RP 2, RP 3, RP 4, and RP 5 respectively. On the contrary, more amount of the resources, i.e. 57 percent, 46 percent, 53 percent, and 80 percent of the total listed materials are fake (uncited materials in the texts) in RP 2, RP 3, RP 4, and RP 5 respectively. It can be a serious issue for the academicians and concerned authorities in the scholastic fields; colleges and universities.

Though the way of mentioning in-text citations in the reports seems relatively uniformed in line with the American Psychological Association (2010) style except for some inconsistencies, such as ... 'Sharma Tank (2010) unpublished research...' (RP 2, p. 12); 'Harmet (2004: 9) states... (RP 3, p. 41); 'Edward Deci (1975, p. 23) writes...' (RP 4, p. 5); and some others in the same nature, relatively more incongruities are found in the way the researchers used the style in referencing in their research reports. One example from this kind of inaptness is presented in Figure 4 below.

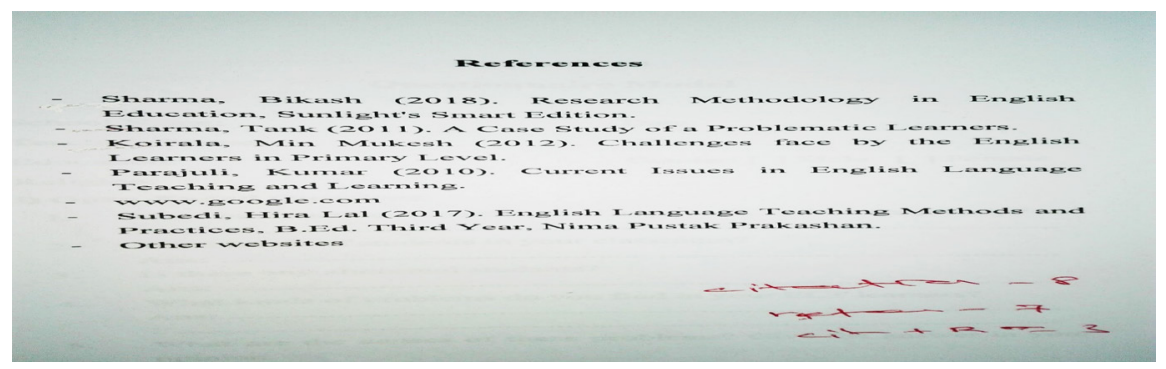

Figure 4: Referencing style incorporated in RP 2 (p. 26) 
The referencing style exhibited in Figure 4 does not match with the APA (2010) and it does not correspond with any of the other existing referencing styles in the academic field, either. The authors' names, the title of the materials (books, theses, etc.), are written differently. Unnecessarily dash (-) before the authors' name is printed but important component publication place is left in writing. Similarly, the materials are placed haphazardly in terms of alphabetical order and hanging indent is not managed. Specific materials used from the websites are to be mentioned but not the general ones as provided in Figure 4. It reveals that the students show their weakness (ignorance?) in following the provision of the appropriate citation and referencing style. Improvement is possible by making familiar the students with a suitable citation and referencing style and encouraging them to apply in practice.

\section{Challenges faced by teachers and students}

In this sub-section, I have interpreted the challenges faced by the teachers while preparing the students for research reports and the students while getting readyfor the research reports to submit at the campus for practical examinations.

\section{Regularities of the students}

Absenteeism in the study time from the part of the students is a great challenge to improve the quality of the students in research. Teachers and students of sampled campuses support that one of the reasons for students' poor performance is the irregularities of the students in the classrooms. Regarding the issues found in the report prepared by the students, a teacher states that "The majority of the students are irregular in the classrooms at the time of teaching-learning activities on campus" (Engt1). He put a question to me "How can we improve the quality of the students in this condition?" Because of this, students remain lack proper guidance (Bhattarai, 2001). Supporting the same view Engt4 mentions that "Most of the students studying in the fourth year [B. Ed.] on our campus are teaching in some of the schools located far from here, so they cannot attend the class regularly".

Students studying in the sampled campuses have similar opinions with the teachers regarding their regularities on campuses. One of the students clearly stated that "I have been teaching in a private school for 
two years, because of my job I could not take my classes in the campus" he also added that "to prioritize job is my compulsion due to my poor economic condition in my home" (Stud3). In backing the same view Stud5 indicated that "Teaching is one of the main opportunities and becomes a source of income for the people living in the village. I have been teaching in a rahat quota since last year". She clearly told me that she could even not participate in the special report preparation classes conducted on campus for the practical examinations. Stud1, Stud2, and Stud4 put the common views concerning the absenteeism of the more number of students in the classrooms.

The students' and teachers' opinions stated here are consistent with some of the past research findings conducted nationally and internationally. The main report of the National Assessment of Student Achievement 2018 conducted in the 1400 schools of Nepal, found that the students who received regular feedback from the teachers had better achievement than those who did not get feedback from the teachers(Ministry of Education Science Technology, 2019). Regular feedback is only possible if the students attend the classrooms regularly. Ministry of Education (2074 BS) also mentioned that the regularity of the students is one of the factors of better achievement. Similarly, some studies conducted internationally (e.g., Boroujeni, Sharma, Kidzinski, Lucignano, \& Dillenbourg, 2016; Jain \& Shrivastav, 2017)carried out in classroom-based learning context, have consistently shown a positive relationship between students' regularity and their academic success, i.e. academic achievement. The regular absence of the students hampers in achieving the targeted goals as mentioned by Lynch and Ndyetabura (1983);Abrahams and Millar (2008); andFaculty of Education (2015). So, to improve the quality of the students in research, students are supposed to attend the classes regularly.

\section{Orientation programs from the concerned authority}

Teachers feel comfortable implementing the new course when they get a chance to participate in the orientation programs, workshops, seminars, or similar programs of this kind about the course introduced by the faculties or institutions under university (Rijal, Karki, \& Adhikari, 2014). With reference to the new course, i.e. Research Methods in English Education, especially for the practical portion, the teachers seem to have 
confusion about the content and the structure of the report to be prepared by the students for the final assessment. Two separate copies (proposal and report) were submitted by the students of Camp 2 and similar to this, the students of Camp 4 submitted two copies, i.e. a research report and another describing their work to be completed in each unit referring to the syllabus entitled 'Unitwise Project Work Portfolio', to the examiners. The students of the rest of the campuses (Camp 1, Camp 3, and Camp 5) each prepared a single paper (report) only. The length and content of the reports the students submitted also varies (mentioned in the 'content' sub-heading above) among the campuses.

Regarding the variations of the reports, the teachers shared common views that they have not been provided any type of specific guidelines nor they received any kind of orientation programs to prepare the reports. During the interview time, a teacher expressed that "I hoped to get either guidelines or an orientation program for preparing the reports from the authorities of FOE but I was not able to get any of these, and I oriented my students on my own ways" (Engt 2). Engt 3, and Engt 5 also shared analogous opinions with Engt 2 while guiding the students in preparing the research reports. Orientation programs for the teachers are very useful to implement the courses in practice. Providing similar opinions, Kölling and Rosenberg (2001)argue that without the orientation program from the concerned authorities relating to the new courses, teachers perceive difficult to implement, and as a result, inconsistencies appear among the institutions even under the same faculties.

\section{CONCLUSION}

Subject teachers hold a crucial role to make the students competent in research as objectified in the course. The teachers provide the basic concept of research to the students theoretically and make them able to prepare the final research reports practically. They need clear guidelines from the concerned authorities to guide the students, especially in the practical portion. The study concluded that lack of chance to share knowledge through orientation programs, seminars, and workshops concerning the practical portion of this course among the teachers from the concerned authorities as well as irregularities of the students appear as challenging to meet the objectives of the course. 
To fulfill the objectives specified in the course, i.e. to assist students to understand the basic concepts and processes of doing and writing research in English language education, several people and institutions should equally be responsible from respective sides. Improvement of the quality of research is essential to achieve the specified objectives stated in the course. Two things can be done to minimize the challenges: to make the policies at macro and micro levels and implement in the respective levels to organize different programs to support the teachers, and to attract the students to attend the classes on their campus regularly.

\section{REFERENCES}

Abrahams, I., \& Millar, R. (2008). Does practical work really work? Astudy of the effectiveness of practical work as a teaching and learning method in school science. International Journal of Science Education, 30(14): 1945-1969. https://doi.org/10.1080/09500690701749305

American Psychological Association. (2010). Publication manual of the American Psychological Association (6th ed.). Washington, DC: Author.

Attride-Stirling, J. (2001). Thematic networks: An analytic tool for qualitative research. Qualitative Research 1(3): 385-405. https:// doi.org/10.1177/146879410100100307

Bhattarai, G. R. (2001). Is the practical examination really practicable? Journal of NELTA, 6(1): 23-35.

Boroujeni, M. S., Sharma, K., Kidzinski, L., Lucignano, L., \& Dillenbourg, P. (2016). How to quantify student's regularity? In: K. Verbert, M. Sharples, \& T. Klobučar (Eds.), Adaptive and adaptable learning: 11th European conference on technology enhanced Learning, EC-TEL 2016, Lyon, France, https://doi.org/10.1007/978-3-31945153-4_21

Creswell, J. W., \& Miller, D. L. (2000). Determining validity in qualitative research. Theory into Practice, 39(3): 124-130.

Denzin, N. K. (1978). The research act: A theoretical orientation to sociological methods (2nd ed.). New York: McGraw-Hill.

Denzin, N. K. (1989). Interpretive interactionism. Newbury Park, CA: Sage. 
Denzin, N. K., \& Lincoln, Y. S. (2011). Handbook of qualitative research (4th ed.). Thousand Oaks, CA: Sage Publications, Inc.

Denzin, N. K., \& Lincoln, Y. S. (2018). The SAGE handbook of qualitative research. Los Angeles: SAGE Publications.

Faculty of Education. (2015). Courses of four-year B.Ed.: Annual system. Kirtipur: Office of the Dean, FOE.

Jain, P., \& Shrivastav, R. (2017). Role of class regularity in academic achievement of higher secondary class students. International Journal of Marketing and Management Research, 8(9). https://www.academia.edu/34907517/ROLE_OF_CLASS REGULARITY_IN_ACADEMIC_ACHIEVEMENT_OF_ HIGHER_SECONDARY_CLASS_STUDENTS, Accessed: $15 / 08 / 2020$.

Kölling, M., \& Rosenberg, J. (2001). Guidelines for teaching object orientation with Java. ACM SIGCSE Bulletin, 33(3): 33-36. https:// kar.kent.ac.uk/13607/1/guidelines_for_teaching_object_kolling. pdf (Accessed: 19/09/2020)

Kumar, R. (2019). Research methodology: A step-by-step guide for beginners (5th ed.). Thousand Oaks: Sage Publications Limited.

Lincoln, Y. S., \& Guba, E. G. (1985). Naturalistic inquiry. Newbury Park, CA: Sage.

Lynch, P. P., \& Ndyetabura, V. L. (1983). Practical work in schools: An examination of teachers' stated aims and the influence of practical work according to students. Journal of Research in Science Teaching, 20(7): 663-671.

Maxwell, J. A. (2013). Qualitative research design: An interactive approach (3rd ed.). Thousand Oaks: Sage publications.

Ministry of Education. (2074 BS). A study on factors of student learning achievements and dynamics for better learning conditions: A case study focused to grade five in some selected schools. Sanothimi, Bhaktapur: Department of Education.

Ministry of Education Science Technology. (2019). National assessment of student achievement 2018: Main report. Sanothimi, Bhaktapur: Education Review Office. 
Rijal, R. R., Karki, T. M., \& Adhikari, K. (2014). Practical works and their exams in three-year B.Ed. English language courses: A follow up study. (Faculty research), University Grants Commission, Sanothimi, Bhaktapur.

Tracy, S. J. (2020). Qualitative research methods: Collecting evidence, crafting analysis, communicating impact (2nd ed.). River Street: Wiley Blackwell.

Tribhuvan University. (2020). TU Today - 2077 (2020-2021 A. D.). Kathmandu: Information \& Public Relation Division, TU. 